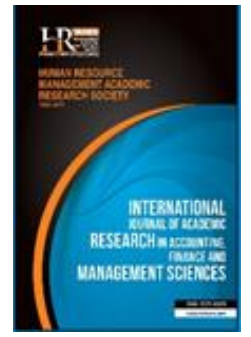

International Journal of Academic Research in Accounting, Finance and Management Sciences

Vol. 9, No.1, January 2019, pp. 54-64

E-ISSN: 2225-8329, P-ISSN: 2308-0337

(c) 2018 HRMARS

www.hrmars.com

To cite this article: Balluchi, F., Furlotti, K., Mazzieri, M., Torelli, R. (2019). Corporate Social Responsibility Disclosure in Italy: An Analysis of the Last Years, International Journal of Academic Research in Accounting, Finance and Management Sciences 9 (1): 54-64

\title{
Corporate Social Responsibility Disclosure in Italy: An Analysis of the Last Years
}

\author{
Federica Balluchi ${ }^{1}$, Katia Furlotti ${ }^{2}$, Michele Mazzieri ${ }^{3}$, Riccardo Torelli ${ }^{4}$ \\ 1,2,3,4 University of Parma - Department of Economics and Management, Via J.F. Kennedy, 6 - 43125 Parma, Italy, \\ ${ }^{1}$ E-mail: federica.balluchi@unipr.it, 2E-mail: katia.furlotti@unipr.it, \\ ${ }^{3}$ E-mail: 230688mm@gmail.com, ${ }^{4}$ E-mail: riccardo.torelli@unipr.it
}

\begin{abstract}
Corporate Social Responsibility Disclosure (CSRD) is the process of communicating the social, ethical and environmental effects of organizations' economic actions. It is a formal commitment to inform and involve stakeholders with an adequate flow of communication through suitable channels, focusing on relevant content. The aim is to study voluntary disclosure implemented by Italian listed companies in the last 9 years (2008-2016). The empirical survey covers data and information on 165 companies. We have analysed: 1) the extent of CSRD in Italy; 2) the characteristics of voluntary disclosure in terms of type of report published and guidelines or standards followed; 3) the main differences between the industrial sectors about the publication of non-financial reports and the types of report used. Our findings show a significant improvement in the practice of voluntary disclosure of Italian listed companies and a key role of industry in decisions regarding the quantity and quality of non-financial disclosure. The value of this research concern in the wide (in time, through the last nine years, and in space, through the different industries) point of view through which is investigated the phenomenon of CSRD in Italy before the shift from a voluntary to a legislative perspective.
\end{abstract}

Key words

CSR; non-financial disclosure; voluntary disclosure; Italy; content analysis

Received: 15 Mar 2019 (c) The Authors 2019

Revised: 30 Mar 2019 Published by Human Resource Management Academic Research Society (www.hrmars.com)

Accepted: 15 Apr 2019 This article is published under the Creative Commons Attribution (CC BY 4.0) license. Anyone may Published Online: 05 May 2019 reproduce, distribute, translate and create derivative works of this article (for both commercial and non-commercial purposes), subject to full attribution to the original publication and authors. The full terms of this license may be seen at: http://creativecommons.org/licences/by/4.0/legalcode

\section{Introduction}

Corporate Social Responsibility Disclosure (CSRD) can be defined as «the process of communicating the social, ethical and environmental effects of organizations' economic actions to particular interest groups within society and to society at large» (Gray et al., 1987). It is part of the formal commitment to inform and involve stakeholders' with an adequate flow of communication through suitable channels, focusing on relevant content. CSRD plays a key role in this commitment: to provide transparent and reliable information is widely considered important for legitimacy (Gray et al., 2001; Campbell, 2004; Kaptein, 2007). Researchers in Italy and around the world have focused on CSR from various perspectives. Most studies focus on the spread of social and environmental reporting in different countries, studying the attitude of medium and large firms to social and environmental communication (Marimon et al., 2012; Hahn and Kühnen, 2013).

A growing number of professional and academic institutions and organizations promote the implementation of CSR reporting and supply useful guidelines for helping company disclosure. In certain 
countries, such as France, Sweden, Norway, Netherlands, Denmark and Australia, firms are under legal obligation to disclose socio-environmental performance. In Italy, only since financial year 2017 have large companies been obliged to report on social and environmental performance (D.Lgs. 30/12/2016, n. 254). Before 2017, they could opt to disclose CSR information at their own discretion in standalone reports, such as social, sustainability or environmental reports, or to combine all economic, social and environmental information in an integrated report.

Starting from this premise and considering that in Italy most CSR studies have been performed on SMEs, and focusing mainly on issues related to CSR strategies rather than on CSRD (e.g. Matacena and Del Baldo, 2009; Caroli and Tantalo, 2010; Del Baldo, 2010), we present an explorative study using a qualitativequantitative approach. The aim of this work is to analyze voluntary CSR communication implemented by Italian listed companies for the period 2008-2016 i.e. before financial year 2017. The study focuses on the following research questions:

$R Q_{1}:$ What is the extent of CSRD in Italy and how has it evolved during the last 9 years?

$R Q_{2}:$ What are the characteristics of voluntary disclosure in terms of type of reports and guidelines followed?

$R Q_{3}:$ Which are the main differences between the industrial sectors about the publication of nonfinancial reports and the types of report used?

The empirical survey covers qualitative-quantitative data and information on 165 Italian listed companies excluding the sectors of banking, finance and insurance. For each company we analyze the type of published report (social, sustainability, environmental, intangible and integrated report) and the reporting standard or guideline used.

\section{Literature review}

Given its importance, especially for strategy, CSRD has been an important focus of academic interest from the 1980s (e.g. Wiseman 1982; Guthrie and Parker, 1989; Roberts, 1992; Gray et al., 1995; Deegan and Gordon, 1996; Neu et al., 1998).

Because of the large number of studies on CSRD, there are several overview studies, which specifically review the existing corporate social responsibility disclosure literature, proposing different classification frameworks (Gray et al., 1995; Mathews, 1997; Gray, 2002; Belal and Momin, 2009; Parker 2011 and 2014; Fifka, 2013; Ali et al., 2017).

Recent CSRD studies focus on several main topics. Some focus on the theories related to CSR and disclosure, in particular legitimacy theory (Tilling and Tilt 2010; Georgiou and Jack 2011), agency theory (Clarkson et al., 2008; Dhaliwal et al., 2012) and neo-institutional theory (Campbell, 2007; Hiss, 2009). Other studies focus on the reasons why companies opt to disclose their CSR commitment at their own discretion (Kolk and Pinkse, 2010; Schmeltz, 2012). These reasons can be related to company reputation, customer loyalty and/or customer-company identification.

A further stream of literature focuses on the relevance of CSRD. Dhaliwal et al. (2012) investigate the relevance of CSR information for the market: CSRD seems to offer relevant information to investors about firm's financial performance or to reduce the cost of equity capital. Moreover, CSR reporting can indicate the ethical values of the company better than mandatory disclosure (Lewis and Unerman, 1999). It can contribute to the democratic development of an effective social responsibility policy, underscoring the key role of "civil society" in supporting these changes (Spence, 2009) and it can increase transparency and thus enhance democracy (Brown, 2009; Spence, 2009). Other research underlines the relevance of CSR standalone reports because they can signal higher firm commitment to social and environmental issues (Mahoney et al., 2013).

An important part of the literature focuses on completeness and credibility of CSR information (Gray, 2010; Amran et al., 2014) and its potential benefits relative to investors and financial stakeholders (Dhaliwal et al., 2012 and 2014). Some researchers raise doubts over the significance of CSRD for investors (Kolk et al., 2001) by suggesting that voluntary social disclosures in the annual report is simply an attempt to gain legitimacy (Kent and Zunker, 2013) or to influence public perception (Neu et al., 1998). Among these studies, several analyse the effectiveness of CSR disclosure (Peterson, 2004; Weber, 2008). They examine its role as a signal of concern for social and environmental issues, or an opportunity to camouflage 
corporate activities and insinuate a corporate image which differs from reality (Cho et al., 2010; Mahoney et al., 2013), enabling the falsification of company image (Hopwood, 2009).

Furthermore, with regard to the credibility of CSRD, several studies underline the importance of the assurance of the documents (Nwanyanwu, 2017), although with some critical viewpoints (Adams and Evans 2004). Many studies emphasize a scarcity of technical abilities and assurance-provider independence (Dando and Swift 2003); other studies reveal that the benefits of assurance are limited to perceptions of the company image (Cho et al., 2014; Wong and Millington, 2014). On the other hand, other studies indicate the importance of rigorous independent verification processes (Zorio et al., 2013).

Otherwise, an important stream of research focuses on the instruments of CSRD and on standards used for drafting the reports. In recent years, these studies have focussed on the integrated report (FriasAceituno et al., 2014; Stubbs and Higgins 2014; de Villiers et al., 2016), and several researchers analyse the differences between an integrated report and other types of standalone report, especially a sustainability report (Mio et al., 2016).

Regarding standards and guidelines used to determine reporting content, several studies point out the importance of developing standards to meet the need for transparent and reliable information (Botelho et al., 2015; Christensen, 2002; Dando and Swift, 2003). This field of study underlines the importance of the Global Reporting Initiative (GRI) guidelines (Brown et al., 2009; Marimon et al., 2012), which are considered the best available option for companies in reporting on CSR issues (Gray, 2010; Mahoney et al., 2013). Several studies confirm the importance of GRI guidelines for company reporting activities (Marimon et al., 2012; Mahoney et al., 2013; Michelon et al., 2015) and underline that they support transparency in reporting (Fernandez-Feijoo et al., 2014). The GRI is however also subject to the criticism that the sustainability principle can appear vague and thus allows companies to make subjective use of guidelines (Moneva et al., 2006).

Many studies explore the relationship between a firm's propensity for CSRD and company characteristics. Characteristics include:

- industry: studies show a strong relationship between industry and CSRD (Brammer and Pavelin 2008; Buniamin, 2010; Kansal et al., 2014);

- size: studies are coherent and show that company size has a significant positive relationship with social and environmental disclosure (Brammer and Pavelin, 2008; Holder-Webb et al., 2008; Cho et al., 2010; Bayoud et al., 2012);

- financial performance: studies show different results; a significant positive relationship (Tagesson et al., 2009), and an insignificant relationship (Cormier et al., 2005; Reverte, 2009; Chih et al., 2010);

- corporate governance: governance structures (Albawwat and Basah 2015; Jo \& Harjoto, 2012; Michelon and Parbonetti, 2012) and corporate executives' attitudes toward disclosure (Adams, 2002; O’Dwyer, 2002);

- stockholder composition (Chau and Gray, 2002; Ghazali, 2007).

Finally, the majority of Italian CSR studies focus on SMEs, and mainly on issues related to CSR strategies rather than CSRD (Matacena and Del Baldo, 2009; Caroli and Tantalo, 2010; Del Baldo, 2010). Until financial year 2016, medium and large firms in Italy could opt to disclose CSR at their own discretion in standalone reports. For both these reasons, Italy is a fruitful field for new research.

\section{Methodology of research}

\subsection{Aims and data collection}

With these premises, the present study analyses voluntary CSRD implemented by Italian companies listed on the Italian Stock Exchange in the period 2008-2016.

The research questions are as follows:

$\mathrm{RQ}_{1}$ : What is the extent of Italian CSRD and how has it evolved during the last 9 years (2008-2016)? (Marimon et al., 2012; Hahn and Kühnen, 2013);

$\mathrm{RQ}_{2}$ : What are the characteristics of voluntary disclosure in terms of type of report and guidelines or standards followed? (Frias-Aceituno et al., 2014; Mio et al., 2016);

$\mathrm{RQ}_{3}:$ Which are the main differences between the industrial sectors about the publication of nonfinancial reports and the types of report used? (e. g. Brammer and Pavelin, 2008) 
The empirical survey considers qualitative-quantitative characteristics of information processes, and consists of three main phases:

1) an exploratory examination of Italian listed companies to identify the number of firms disclosing CSR information in specific stand-alone reports in the period 2008-2016;

2) an analysis of the reports published in that period in terms of type of document (social, sustainability, environmental, intangible and integrated report) and reporting standards used (especially "Gruppo di Studio per il Bilancio Sociale" - GBS and "Global Reporting Initiative" - GRI);

3) an analysis of the differences between different industries focusing on the number of nonfinancial reports published and on the type of non-financial reports used. period:

Companies in our sample were required to meet the following requirements for the entire nine-year

1) continuous listing on the Italian Stock Exchange;

2) not belonging to banking, financial or insurance industries. This is because of the different characteristics of their equity and because these firms are not comparable with firms of other industries (La Porta et al., 2002).

Our final sample comprised 165 companies for which we have nine years of observations.

\subsection{Results and discussion}

The number of observations is constant throughout the time period 2008 2016. Companies are from nine industries. We adopt the Industry Classification Benchmark (ICB), globally recognized industry classification taxonomy. 0) Oil \& Gas; 1) Basic Materials; 2) Industrials; 3) Consumer Goods; 4) Health Care; 5) Consumer Services; 6) Telecommunications; 7) Utilities; 8) Financials (excluded for the reasons mentioned above); 9) Technology. Our sample contains a prevalence of industries 1) Basic Materials and 3) Consumer Goods (Table 1).

Table 1. Frequencies over industries

\begin{tabular}{|c|c|c|c|}
\hline $\mathrm{n}$. & Industry & Frequency & Percent \\
\hline 0 & Oil \& Gas & 55 & 3.70 \\
\hline 1 & Basic Materials & 459 & 30.91 \\
\hline 2 & Industrials & 63 & 4.24 \\
\hline 3 & Consumer Goods & 341 & 22.96 \\
\hline 4 & Health Care & 63 & 4.24 \\
\hline 5 & Consumer Services & 99 & 6.67 \\
\hline 6 & Telecommunications & 135 & 9.09 \\
\hline 7 & Utilities & 126 & 8.48 \\
\hline 9 & Technology & 144 & 9.70 \\
\hline & Total & 1485 & 100.00 \\
\hline
\end{tabular}

With reference to RQ1 and RQ2, we found that in $23 \%$ of 1485 total observations over the entire period, firms opted for a voluntary reporting system, using different types of report (Table 2). The item "Other report" covers a small number of very specific tools such as the SA8000 and ethical rating reports, usually one or two page CSR documents which cannot be considered real reports.

Table 2. Descriptive Statistics of variables

\begin{tabular}{|c|c|c|c|c|c|c|c|c|}
\hline & & $\begin{array}{l}\text { Voluntary } \\
\text { Disclosure }\end{array}$ & Social & Sustainability & Environment & al Intangible & Integrated & Other report \\
\hline & $\mathrm{N}$ & 1485 & 1485 & 1485 & 1485 & 1485 & 1485 & 1485 \\
\hline Mean & & 0.2276 & 0.0094 & 0.1751 & 0.0168 & 0.0000 & 0.0121 & 0.0114 \\
\hline Std. Deviation & & 0.4194 & 0.0967 & 0.3802 & 0.1287 & 0.0000 & 0.1095 & 0.1064 \\
\hline Minimum & & 0.00 & 0.00 & 0.00 & 0.00 & 0.00 & 0.00 & 0.00 \\
\hline Maximum & & 1.00 & 1.00 & 1.00 & 0.00 & 0.00 & 1.00 & 1.00 \\
\hline
\end{tabular}

Focussing on the year-by-year situation, Figure 1 shows clearly a steady increase in CSRD (RQ1). In fact in 2008 only 26 companies out of 165 made voluntary disclosure (16\%) and in 2016, the number was 
$51(31 \%)$. Among the various CSR tools (RQ2), the sustainability report is the most widely used type (43 companies out of 51 in 2016).

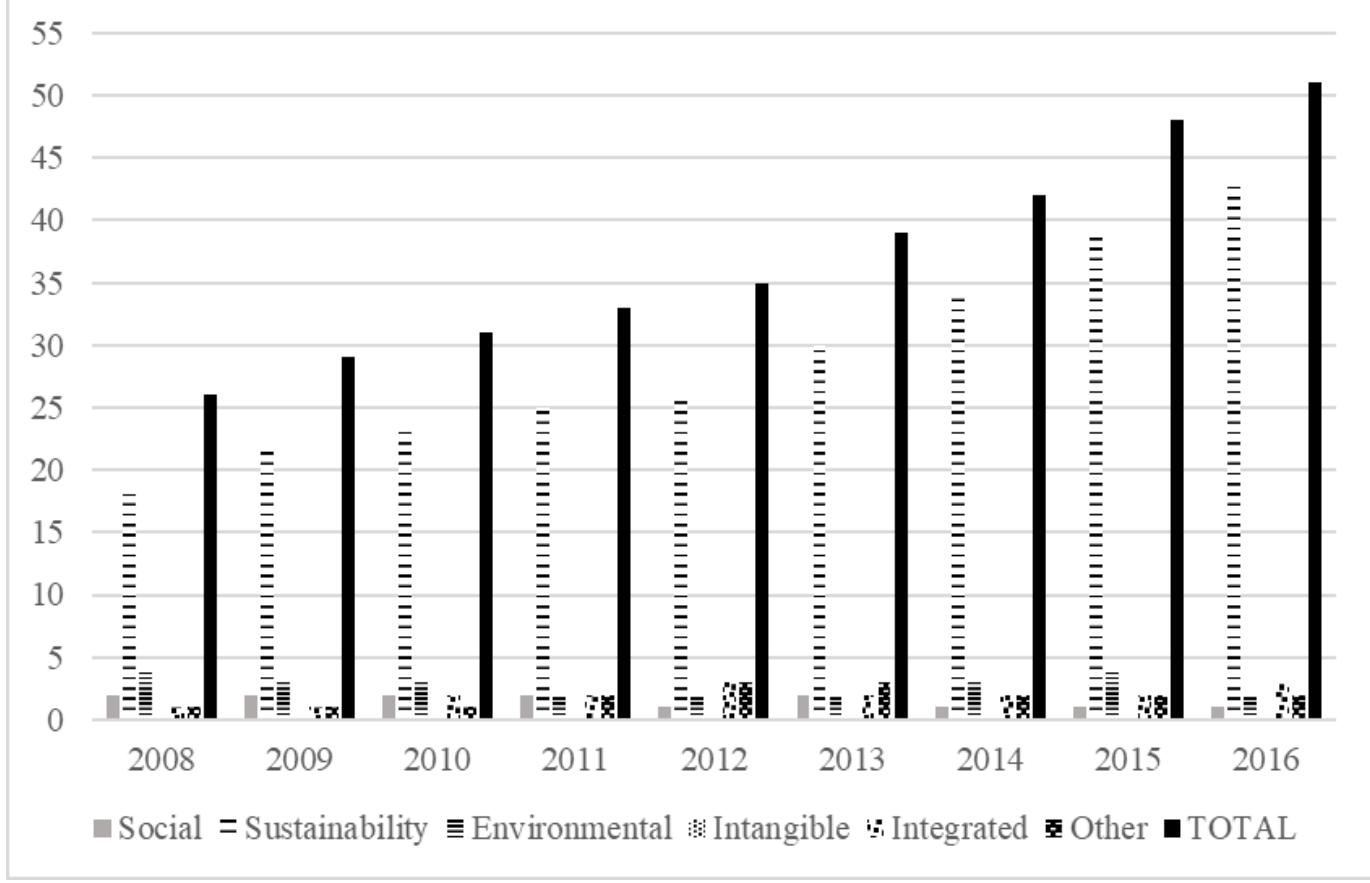

Figure 1. Voluntary Disclosure by year

Among the guidelines used to draw up voluntary disclosure documents (RQ2), GRI Standards are the most frequently used including when the company discloses CSR information with a social or integrated report. In 2008, 20 firms adopted the GRI Standards and in 201648 firms. Apart from GBS which is used by 4 companies in 2008 and 8 in 2016, the other guidelines or standards are proxy to $0 \%$ in all years (Figure 2).

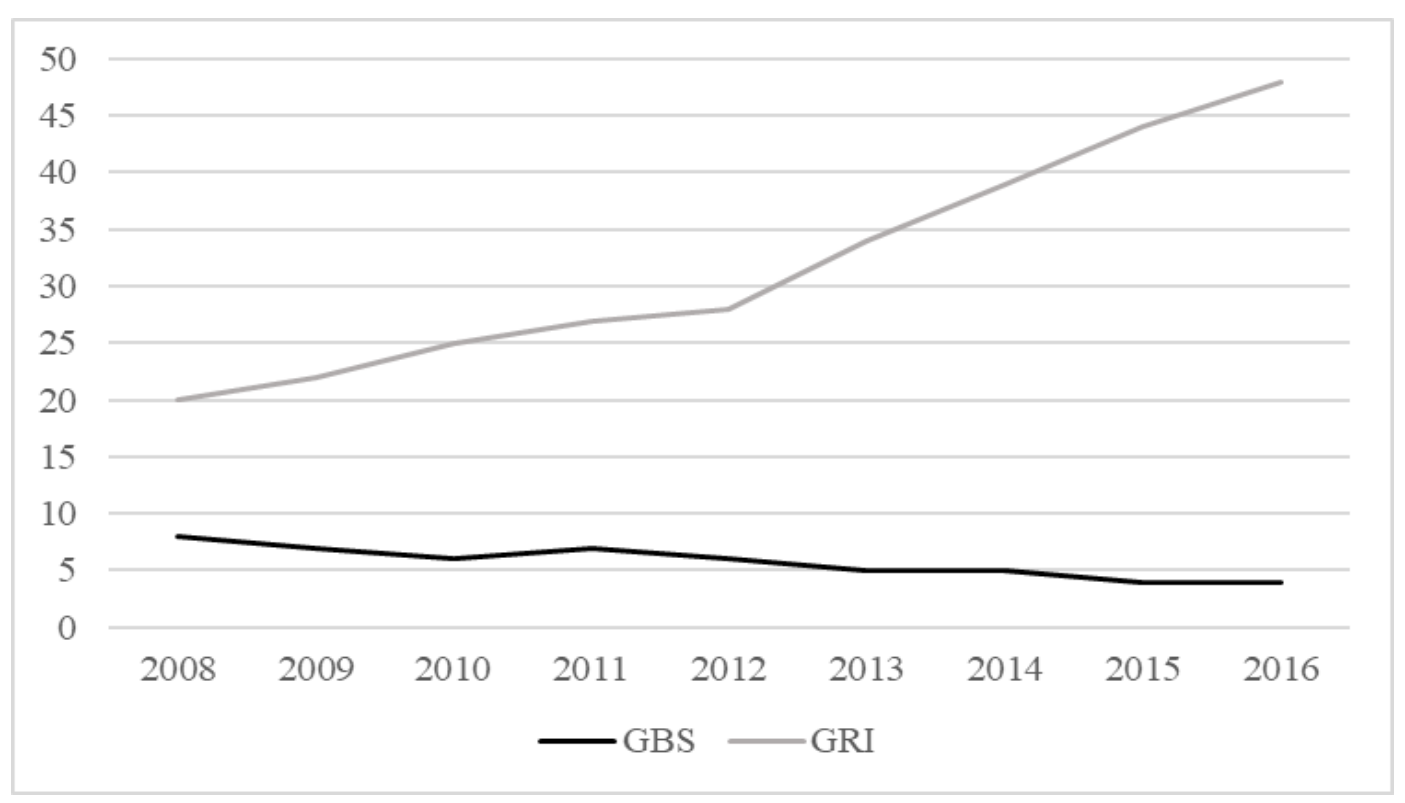

Figure 2. GRI and GBS by year

Regarding the RQ3 we have conducted an industry-level analysis and submitted the differences calculated to a T-test (Table 4). The T-test assumes the null hypothesis that the average of voluntary disclosure values in each of the nine industries ( 1 if it is present, 0 if it is not present) is equal to the average of the same values in the rest of the sample. 
Table 4. Group mean-comparison test: Voluntary Disclosure in different industries

\begin{tabular}{llcccc}
\hline $\mathbf{n}$. & \multicolumn{1}{c}{ Industry } & Industry mean & Rest of sample mean & Difference & T-test \\
\hline 0 & Oil \& Gas & 0.6545 & 0.2112 & 0.4434 & $-7.8482^{* * *}$ \\
1 & Basic Materials & 0.2352 & 0.2242 & 0.0110 & -0.4721 \\
2 & Industrials & 0.3968 & 0.2201 & 0.1767 & $-3.2832^{* * *}$ \\
3 & Consumer Goods & 0.0850 & 0.2701 & -0.1851 & $7.2753^{* * *}$ \\
4 & Health Care & 0.0476 & 0.2356 & -0.1880 & $3.4939^{* * *}$ \\
5 & Consumer Services & 0.2222 & 0.2280 & -0.0058 & 0.1322 \\
6 & Telecommunications & 0.1556 & 0.2348 & -0.0793 & $2.0958^{* *}$ \\
7 & Utilities & 0.6270 & 0.1906 & 0.4364 & $-11.6706^{* * *}$ \\
9 & Technology & 0.1042 & 0.2409 & -0.1367 & $3.7327^{* * *}$ \\
\hline
\end{tabular}

* $p<0.10 ;{ }^{* *} p<0.05 ;{ }^{* * *} p<0.01$

Table 4 shows that companies in Oil \& Gas, Industrials and Utilities industries have a higher industry mean value compared to the rest of sample mean value, and a significant result in the T-test. Firms belonging to these industries tend to produce significantly more voluntary disclosure reports than other firms. Conversely, Consumer goods, Health Care, Telecommunications and Technology industries are less inclined to adopt a CSR reporting tool than firms belonging to the other industries.

These results confirm previous findings. Brammer and Pavelin (2006), for example, found that companies operating in high-tech and finance industries are less inclined to use a voluntary disclosure process (the finance industry was not considered in our sample), whereas companies operating in industries with a high environmental impact are more inclined to use one.

It is interesting and important to understand in which industries, in Italy, there is a greater use and dissemination of voluntary disclosure tools and reports. The previous results show us that also in the last nine years of voluntary non-financial disclosure in Italy we find a greater propensity to produce and publish social/environmental information in companies with particular social and environmental impactful activities. Stakeholder pressures, general need of more information about corporate activities, the even more attention and importance that is given to the social and environmental impacts, but also local and national regulations about these particular activities and impacts could be the motives behind the greater use of voluntary disclosure tools. It is then fundamental to understand in which sectors we find this phenomenon, not only to measure the attention paid by stakeholders, society in general and local/national legislators, but also to understand which the approaches of the companies in these industries are and what are their answers. This is particularly interesting and useful for the legislator because this study is based on the nine years before the change from a voluntary approach to the non-financial disclosure to a mandatory one and in these firsts years of the new regulatory it could be very useful to understand the previous practices in the different industries, where there were a greater (or lesser) inclination to give this type of information, and where to identify and study the best-practice (or the more expert) companies in this field of reporting.

In the last analysis (Table 5) we have deepened the dissemination of the different types of nonfinancial report among the different industries in the nine-year period under investigation.

Table 5. Different reports (expressed in \% on the total number of non-financial reports published in the 9 years in the particular industry) in different industries

\begin{tabular}{lcccccc}
\hline \multicolumn{1}{c}{ Industry } & Social & Sustainability & Environmental & Intangible & Integrated & Other \\
\hline Oil \& Gas & 0.00 & 66.67 & 0.00 & 0.00 & 8.33 & 25.00 \\
Basic Materials & 5.66 & 67.92 & 12.26 & 0.00 & 13.21 & 0.94 \\
Industrials & 0.00 & 100.00 & 0.00 & 0.00 & 0.00 & 0.00 \\
Consumer Goods & 0.00 & 84.62 & 0.00 & 0.00 & 0.00 & 15.38 \\
Health Care & 0.00 & 100.00 & 0.00 & 0.00 & 0.00 & 0.00 \\
Consumer Services & 0.00 & 100.00 & 0.00 & 0.00 & 0.00 & 0.00 \\
Telecommunications & 0.00 & 85.71 & 0.00 & 0.00 & 0.00 & 14.29 \\
Utilities & 0.00 & 84.52 & 14.29 & 0.00 & 1.19 & 0.00 \\
Technology & 66.67 & 33.33 & 0.00 & 0.00 & 0.00 & 0.00 \\
\hline
\end{tabular}


Through this data we can appreciate the percentage of each type of report used by companies in the specific sector, calculated on the total of non-financial reports of the sector. It's very interesting and deserving of future new insights to notice that in the Italian context, in the years before the new law about mandatory non-financial information, there are notable differences between industries in the use of different kinds of reports. Basic Materials industry is where we have the highest production rate (13.21\%) of Integrated Reports, and maybe in consequences one of the lowest production rate of Sustainability Reports (67.92\%). In this industry we have also a moderate use of Environmental Reports and Social Reports. The only other industry where we have found a use of Environmental Reports (14.29\%) is Utilities industry: in this case we may suppose that the particular activity of companies in this industrial sector is very related to environmental impacts and then with environmental information (and pressure/request of these information). While in the country there is a constant decline in the use of the Social Report is very interesting to see the high production rate of Social Reports (66.67\%) in the Technology industry: we may suppose that companies operating in this industrial sector have to face above all problems concerning the social context and matters concerning personnel and working conditions. Regarding the use of the most recent Integrated Report we can see how, apart from the case of Basic Materials industry, the only two industrial sectors where we find the use are the Utilities industry (1.19\%) and above all the Oil \& Gas industry (8.33\%). These are certainly the two industrial sectors with the highest environmental impact and where the attention of the main stakeholder groups, as well as public institutions, has recently been concentrated. This may be the reason to explain the use of one of the most complete and appreciated (but also criticized) type of non-financial report in the last years.

\section{Conclusions}

The analysis confirms the key role of sector of activity in decisions regarding the quantity and quality of non-financial disclosure. In line with previous studies (Brammer and Pavelin, 2008; Buniamin, 2010; Kansal et al., 2014) set in other countries we find that the industry influences corporate management on decisions about the type of disclosure to be published. Direct and indirect external pressures, socialenvironmental impacts of core business, stakeholder expectations and behaviours of competitors are all factors which influence managerial choices (Fasan and Marcon 2018) on voluntary disclosure and related processes. We find that listed companies operating in areas with a strong social and environmental impact have a higher propensity to engage in CSR disclosure. In this respect, specific regulatory intervention for different sectors could be useful. The study of the characteristics of the companies (and industries) and their reports is particular interesting also because in Italy, the nine-years period under investigation, is the last period with a process of non-financial disclosure entirely voluntary and not mandatory. It is therefore important for understand the real and deepen motivations and pressures behind the choice to disclose CSR information. The general study and the specific results can be useful and interesting for the nation legislator to understand the choices and the real use of non-financial disclosure tools not only in the country but also in particular industrial areas: it can benefit both to better understand the future impact of the new law and to take cues to intervene on individual cases of specific industrial sectors. Also the academic world can be interested in a study of this kind, to understand the peculiarity of the Italian situation before the new law and to use this findings in international comparation.

Future development of this research could be continued on other CSRD elements such as the use of other accountability tools; by improving the empirical analysis inserting other possible correlated elements of Social and Environmental Accounting (SEA) or understanding whether in the new law about mandatory non-financial disclosure there are key elements taken from experience of the last years and in particular from the more active industries. It could be also interesting to analyse the evolution of the production rate of different types of reports after the entry in to force of the national regulation. 


\section{References}

1. Adams, C.A. (2002). Internal Organisational Factors Influencing Corporate Social and Ethical Reporting. Beyond Current Theorizing. Accounting, Auditing and Accountability Journal, 15(2), 223-250.

2. Adams, C.A., \& Evans, R. (2004). Accountability, Completeness, Credibility and the Audit Expectations Gap. Journal of Corporate Citizenship, 14, 97-115.

3. Albawwat, A.H., \& Basah, M.Y. (2015). The Impact of Shariah Approved Companies on the Relationship between Corporate Governance Structure and Voluntary Disclosure of Interim Financial Reporting in Jordan. International Journal of Academic Research in Accounting, Finance and Management Sciences, 5(2), 66-85.

4. Ali, W., Frynas, J.G., \& Mahmood, Z. (2017). Determinants of Corporate Social Responsibility (CSR) Disclosure in Developed and Developing Countries: A Literature Review. Corporate Social Responsibility and Environmental Management, 24(4), 273-294.

5. Amran, A., Lee, S.P., \& Devi, S.S. (2014). The Influence of Governance Structure and Strategic Corporate Social Responsibility toward Sustainability Reporting Quality. Business Strategy and the Environment, 23, 217-235.

6. Bayoud, N.S., Kavanagh, M. \& Slaughter, G. (2012). Factors Influencing Levels of Corporate Social Responsibility Disclosure by Libyan Firms: A Mixed Study. International Journal of Economics and Finance, 4(4), 13-29.

7. Belal, A.R, \& Momin, M. (2009). Corporate Social Reporting (CSR) in Emerging Economies: A Review and Future Direction. Research in Accounting in Emerging Economies, 9(1), 119-143.

8. Botelho, R., Azevedo, G., Costa, A. \& Oliveira, J. (2015). Property, Plant and Equipment disclosure requirements and firm characteristics: the Portuguese Accounting Standardization System. International Journal of Academic Research in Accounting, Finance and Management Sciences, 5(1), 58-71.

9. Brammer S., \& Pavelin, S. (2008). Factors Influencing the Quality of Corporate Environmental Disclosure. Business Strategy \& the Environment, 17(2), 120-136.

10. Brammer, S., \& Pavelin, S. (2006). Voluntary Environmental Disclosures by Large UK Companies. Journal of Business Finance \& Accounting, 33(7/8), 1168-1188.

11. Brown, H.S., de Jong, M., \& Levy, D.L. (2009). Building Institutions Based on Information Disclosure: Lessons from GRI's Sustainability Reporting. Journal of Cleaner Production, 17(6), 571-580.

12. Brown, J. (2009). Democracy, Sustainability and Dialogic Accounting Technologies: Taking Pluralism Seriously. Critical Perspectives on Accounting, 20(3), 313-342.

13. Buniamin, S. (2010). The Quantity and Quality of Environmental Reporting in Annual Report of Public Listed Companies in Malaysia. Issues in Social \& Environmental Accounting, 4(2), 115-135.

14. Campbell, J.L. (2007). Why Would Corporations Behave in Socially Responsible Ways? An Institutional Theory of Corporate Social Responsibility. Academy of Management Review, 32(3), 946-967.

15. Campbell, D. (2004). A Longitudinal and Cross-Sectional Analysis of Environmental Disclosure in UK Companies. A Research Note. British Accounting Review, 36, 107-117.

16. Caroli, M. \& Tantalo, C. (eds.) (2010). Responsabilità sociale d'impresa nel quadro delle Linee Guida OCSE destinate alle imprese multinazionali. Un Focus sulle PMI. Roma: Istituto per la promozione industriale - IPI.

17. Chau, G.K. \& Gray, S.J. (2002). Ownership Structure and Corporate Voluntary Disclosure in Hong Kong and Singapore. The International Journal of Accounting, 27, 247-265.

18. Chih, H.L., Chih H.H., Chen T.Y. (2010). On the Determinants of Corporate Social Responsibility: International Evidence on the Financial Industry. Journal of Business Ethics, 93(1), 115-135.

19. Cho, C.H., Michelon, G., Patten, D.M., \& Roberts, R.W. (2014). CSR Report Assurance in the USA: An Empirical Investigation of Determinants and Effects. Sustainability Accounting, Management and Policy Journal, 5(2), 130-148.

20. Cho, C.H., Roberts, R.W., \& Patten, D.M. (2010). The Language of US Corporate Environmental Disclosure. Accounting, Organizations and Society, 35(4), 431-443.

21. Christensen, L.T. (2002). Corporate Communication: The Challenge of Transparency. Corporate Communications, 7(3), 162-168. 
22. Clarkson, P.M., Li, Y., Richardson, G.D., \& Vasvari, F.P. (2008). Revisiting the Relation Between Environmental Performance and Environmental Disclosure: An Empirical Analysis. Accounting, Organizations and Society, 33(4/5), 303-327.

23. Cormier, D., Magnan, M., \& Van Velthoven, B. (2005). Environmental Disclosure Quality: Do Firms Respond to Economic Incentives, Public Pressures, or Institutional Conditions. European Accounting Review, 14(1), 1-37.

24. Dando, N., \& Swift, T. (2003). Transparency and Assurance: Minding the Credibility Gap. Journal of Business Ethics, 44(2/3), 195-200.

25. de Villiers, C., Venter, E.R., \& Hsiao, P.C.K. (2016). Integrated Reporting: Background, Measurement Issues, Approaches and an Agenda for Future Research. Accounting \& Finance, 57 (4), 937959.

26. Deegan, C., \& Gordon, B. (1996). A Study of the Environmental Disclosure Practices of Australian Corporations. Accounting and Business Research, 26(3), 187-199.

27. Del Baldo, M. (2010). Corporate Social Responsibility and Corporate Governance in Italian SMEs: The Experience of Some "Spirited Businesses". Journal of Management and Governance, 16 (1), 1-36.

28. Dhaliwal, D.S., Radhakrishnan, S., Tsang, A., \& Yang, Y.G. (2012). Nonfinancial Disclosure and Analyst Forecast Accuracy: International Evidence on Corporate Social Responsibility Disclosure. The Accounting Review, 87(3), 723-759.

29. Dhaliwal, D., Li, O.Z., Tsang, A., \& Yang, Y.G. (2014). Corporate Social Responsibility Disclosure and the Cost of Equity Capital: The Roles of Stakeholder Orientation and Financial Transparency. Journal of Accounting and Public Policy, 33(4), 328-355.

30. Fasan, M., Marcon, C. (2018). Accounting Choice under IFRS: The Role of Accounting Tradition and Managerial Opportunism, International Journal of Academic Research in Accounting, Finance and Management Sciences, 8(3), 209-223.

31. Fernandez-Feijoo, B., Romero, S., \& Ruiz, S. (2014). Effect of Stakeholders' Pressure on Transparency of Sustainability Reports within the GRI Framework. Journal of Business Ethics, 122(1), 53-63.

32. Fifka, M.S. (2013). Corporate Responsibility Reporting and its Determinants in Comparative Perspective. A Review of the Empirical Literature and a Meta-Analysis. Business Strategy and the Environment, 22(1), 1-35.

33. Frias-Aceituno, J.V., Rodríguez-Ariza, L., \& Garcia-Sánchez, I.M. (2014). Explanatory Factors of Integrated Sustainability and Financial Reporting. Business Strategy and the Environment, 23(1), 56-72.

34. Georgiou, O., \& Jack, L. (2011). In pursuit of Legitimacy: A History Behind Fair Value Accounting. The British Accounting Review, 43(4), 311-323.

35. Ghazali, N.A. (2007). Ownership Structure and Corporate Social Responsibility Disclosure: Some Malaysian Evidence. Corporate Governance, 7(3), 251-266.

36. Gray, R. (2002). The Social Accounting Project and Accounting Organizations and Society Privileging Engagement, Imaginings, New Accountings and Pragmatism over Critique? Accounting, Organizations and Society, 27, 687-708.

37. Gray, R. (2010). Is Accounting for Sustainability Actually Accounting for Sustainability and How Would We Know? An Exploration of Narratives of Organisations and the Planet. Accounting, Organizations and Society, 35, 47-62.

38. Gray, R., Owen, D., \& Maunders, K. (1987). Corporate Social Reporting: Accounting and Accountability. London: Prentice-Hall.

39. Gray, R., Kouhy, R., \& Lavers, S. (1995). Corporate Social and Environmental Reporting: A Review of the Literature and a Longitudinal Study of UK Disclosure. Accounting, Auditing and Accountability Journal, 8(2), 47-77.

40. Gray, R., Javad, M., Power, D.M., \& Sinclair, C. (2001). Social and Environmental Disclosure and Corporate Characteristics: A Research Note and Extension. Journal of Business Finance \& Accounting, 28, 327-356.

41. Guthrie, J., \& Parker, L.D. (1989). Corporate Social Reporting: A Rebuttal of Legitimacy Theory. Accounting \& Business Research, 19(76), 343-352. 
42. Hahn, R., \& Kühnen, M. (2013). Determinants of Sustainability Reporting: A Review of Results, Trends, Theory, and Opportunities in an Expanding Field of Research. Journal of Cleaner Production, 59, 521.

43. Hiss, S. (2009). From Implicit to Explicit Corporate Social Responsibility: Institutional Change as a Fight for Myths. Business Ethics Quarterly, 19(03), 433-451.

44. Hopwood, A.G. (2009). Accounting and the Environment. Accounting, Organizations and Society, 34, 433-439.

45. Jo, H., \& Harjoto, M. (2012). The Causal Effect of Corporate Governance on Corporate Social Responsibility. Journal of Business Ethics, 106(1), 53-72.

46. Kansal, M., Joshi, M., \& Batra, G.S. (2014). Determinants of Corporate Social Responsibility Disclosures: Evidence from India. Advances in Accounting, 30(1), 217-229.

47. Kaptein, M. (2007). Ethical Guidelines for Compiling Corporate Social Reports. Journal of Corporate Citizenship, 27, 71-90.

48. Kent, P., \& Zunker, T. (2013). Attaining Legitimacy by Employee Information in Annual Reports. Accounting, Auditing \& Accountability Journal, 26(7), 1072-1106.

49. Kolk, A., \& Pinkse, J. (2010). The Integration of Corporate Governance in Corporate Social Responsibility Disclosures. Corporate Social Responsibility and Environmental Management, 17(1), 15-26.

50. Kolk, A., Walhain, S., \& van der Wateringen, S. (2001). Environmental Reporting by the Fortune Global 250: Exploring the Influence of Nationality and Sector. Business Strategy and the Environment, 10, 15-28.

51. La Porta, R., Lopez-de-Silanes, F., \& Shleifer, A. (2002). Government Ownership of Banks. The Journal of Finance, 57(1), 265-301.

52. Lewis, L., \& Unerman, J. (1999). Ethical Relativism: A Reason for Differences in Corporate Social Reporting? Critical Perspective on Accounting, 10, 521-547.

53. Mahoney, L.S., Thorne, L., Cecil, L., \& LaGore, W. (2013). A Research Note on Standalone Corporate Social Responsibility Reports: Signalling or Greenwashing? Critical Perspectives on Accounting, 24(4/5), 350-359.

54. Marimon, F., del Mar Alonso-Almeida, M., del Pilar Rodríguez, M., \& Alejandro, K.A.C. (2012). The Worldwide Diffusion of the Global Reporting Initiative: What Is the Point? Journal of Cleaner Production, 33, 132-144.

55. Matacena, A., \& Del Baldo, M.D. (eds.) (2009). Responsabilità sociale d'impresa e territorio. L'esperienza delle piccole e medie imprese marchigiane. Milano: Franco Angeli.

56. Mathews, M.R. (1997). Twenty-Five Years of Social and Environmental Accounting Research: Is there a Silver Jubilee to Celebrate? Accounting, Auditing \& Accountability Journal, 10(4), 481-531.

57. Michelon, G., Pilonato, S., \& Ricceri, F. (2015). CSR Reporting Practices and the Quality of Disclosure: An Empirical Analysis. Critical Perspectives on Accounting, 33, 59-78.

58. Michelon, G., \& Parbonetti, A. (2012). The Effect of Corporate Governance on Sustainability Disclosure. Journal of Management and Governance, 16, 477-509.

59. Mio, C., Fasan, M., \& Pauluzzo, R. (2016). Internal Application of IR Principles: Generali's Internal Integrated Reporting. Journal of Cleaner Production, 139, 204-218.

60. Moneva, J., Archel, P., \& Correa, C. (2006). GRI and the Camouflaging of Corporate Unsustainability. Accounting Forum, 30, 121-137.

61. Neu, D., Warsame, H., \& Pedwell, K. (1998). Managing Public Impressions: Environmental Disclosures in Annual Reports. Accounting, Organizations and Society, 23(3), 265-282.

62. Nwanyanwu, L.A. (2017). Audit Quality Practices and Financial Reporting in Nigeria. International Journal of Academic Research in Accounting, Finance and Management Sciences, 7(2), 145-155.

63. O'Dwyer, B. (2002). Managerial Perceptions of Corporate Social Disclosure: An Irish Story. Accounting, Auditing \& Accountability Journal, 15(3), 406-436.

64. Parker, L.D. (2011). Twenty-One Years of Social and Environmental Accountability Research: A Coming of Age. Accounting Forum, 35(1), 1-10.

65. Parker, L. (2014). Constructing a Research Field: A Reflection on the History of Social and Environmental Accounting. Social and Environmental Accountability Journal, 34(2), 87-92. 
66. Patten, D. M. (1992). Intra-Industry Environmental Disclosures in Response to the Alaskan Oil Spill: A Note on Legitimacy Theory. Accounting, Organizations and Society, 17(5), 471-475.

67. Peterson, D. K. (2004). The Relationship between Perceptions of Corporate Citizenship and Organizational Commitment. Business \& Society, 43(3), 296-319.

68. Reverte, C. (2009). Determinants of Corporate Social Responsibility Disclosure Ratings by Spanish Listed Firms. Journal of Business Ethics, 88(2), 351-366.

69. Roberts, R. W. (1992). Determinants of Corporate Social Responsibility Disclosure: An Application of Stakeholder Theory. Accounting, Organizations and Society, 17(6), 595-612.

70. Spence, C. (2009). Social Accounting's Emancipatory Potential: A Gramscian Critique. Critical Perspectives on Accounting, 20, 205-227.

71. Stubbs, W., \& Higgins, C. (2014). Integrated Reporting and Internal Mechanisms of Change. Accounting, Auditing \& Accountability Journal, 27(7), 1068-1089.

72. Tagesson, T., Blank, V., Broberg, P., \& Collin, S. (2009). What Explains the Extent and Content of Social and Environmental Disclosures on Corporate Websites: A Study of Social and Environmental Reporting in Swedish Listed Corporations. Corporate Social Responsibility \& Environmental Management, 16(6), 352-364.

73. Tilling, M.V., \& Tilt, C.A. (2010). The Edge of Legitimacy: Voluntary Social and Environmental Reporting in Rothmans' 1956-1999 Annual Reports. Accounting, Auditing \& Accountability Journal, 23(1), 55-81.

74. Weber, M. (2008). The Business Case for Corporate Social Responsibility: A Company-Level Measurement Approach for CSR. European Management Journal, 26(4), 247-261.

75. Wiseman, J. (1982). An Evaluation of Environmental Disclosures Made in Corporate Annual Reports. Accounting, Organizations and Society, 7(1), 53-63.

76. Wong, R., \& Millington, A. (2014). Corporate Social Disclosures: A User Perspective on Assurance. Accounting, Auditing \& Accountability Journal, 27(5), 863-887.

77. Zorio, A., Garcia-Benau, M.A., \& Sierra, L. (2013). Sustainability Development and the Quality of Assurance Reports: Empirical Evidence. Business Strategy and the Environment, 22, 484-500. 